\title{
The Development of Analytical Chemistry in Brazil: Retrospective and Expectations
}

\author{
Elias A. G. Zagatto * and Sandra M. O. Sá
}

Centro de Energia Nuclear na Agricultura, Universidade de São Paulo, CP 96, 13400-970 Piracicaba - SP, Brazil

O desenvolvimento da Química Analítica no Brasil ao longo do último século é avaliado criticamente em relação ao avanço científico internacional. Tendências para o próximo século são discutidas, especialmente no que tange à expressiva mudança de paradigma atualmente observada.

The development of Analytical Chemistry in Brazil in the last century is critically evaluated in relation to international achievements. Tendencies for the next century are foreseen, especially in relation to the presently observed shifts in paradigm.

Keywords: Analytical Chemistry, historical aspects, Brazil

\section{Introduction}

For a proper discussion of the development of Analytical Chemistry in the last century, the dichotomy between Analytical Chemistry and Chemical Analysis, the mission of Analytical Chemistry, and its role in relation to the other branches of Chemistry, are relevant aspects to be taken into account.

The Analytical Chemistry/Chemical Analysis dichotomy is a consequence of the increase in the demand for chemical assays that often leads to the development of novel concepts, instruments, methods and procedures. This is a driving force towards the improvement of the capabilities of analytical laboratories that, in turn, leads to a further increase in the demand for chemical assays, often generating novel approaches, and so on. This synergy $^{1}$ is illustrated as the recurrent cycle in Figure 1, and may lead to a significant improvement in the conceptual, methodological and applicative aspects involved.

As a consequence of the above-mentioned dichotomy, applications to different sample matrices, development of novel sensors and advanced strategies for data treatment, as well as design of instrumentation amenable to miniaturization, have been progressively emphasized, especially in more recent years. Thus, chemical analysis approached the situation pictured in Figure 2, that caricaturizes a modern "laboratory" devoted to in vivo assays at the beginning of the third millennium.

*e-mail: ezagatto@cena.usp.br

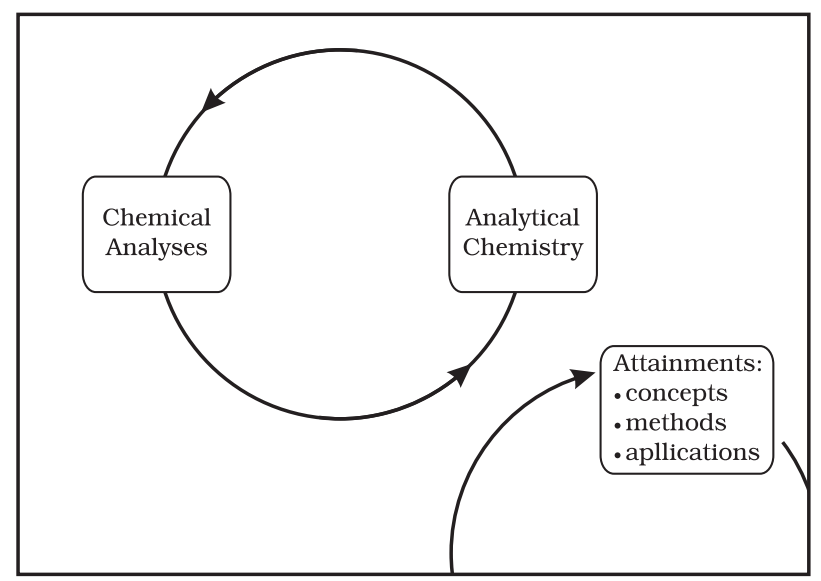

Figure 1. The Chemical Analysis/Analytical Chemistry dichotomy.

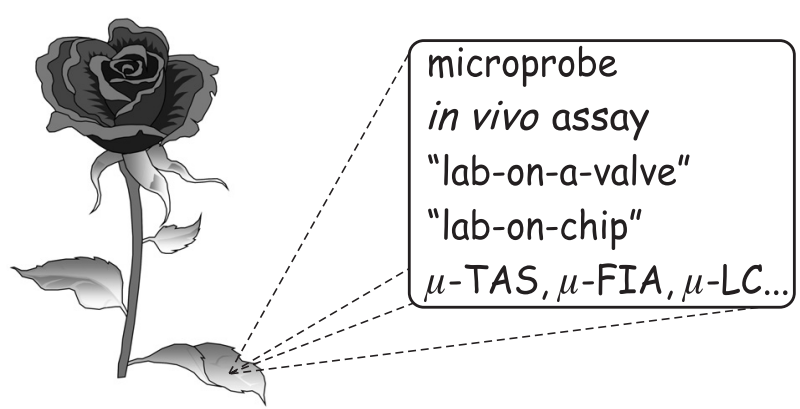

Figure 2. A modern "laboratory" for in vivo analysis.

In view of the continuous development of Analytical Chemistry in the last century, the definition of Analytical Chemistry underwent several expansions, and the saying 
"Analytical Chemistry is a scientific discipline which develops and applies methods, instruments and strategies to obtain information on the composition and nature of matter in space and time"2 should be highlighted. A critical evaluation of this definition reveals that researchers more involved with chemometrics, descriptions of some environmental sites, temporal variations in chemical composition of specific media, advances in instrumentation etc. are nowadays considered as analytical chemists, even if experienced in other fields. This paradigm could probably not be imagined at the beginning of last century.

Another feature inherent to this definition refers to the role of Analytical Chemistry. In the first half of last century, Analytical Chemistry was not imagined as a discipline, and developments were attained in view of the need for assisting related disciplines, such as Physical Chemistry, Organic Chemistry etc. In recent decades, Analytical Chemistry has evolved into a strong and independent discipline that is per se as relevant as the others. This aspect should be considered in describing the evolution of Analytical Chemistry.

The development of Analytical Chemistry in the last century, its present status and the tendency for the next years are discussed herein by considering the relation of the discipline with others, the achievements in Brazil as compared with other countries, the tasks related to the discipline and the dissemination of results, which correspond to identity, adherence, domain and divulgence, respectively. For didactic purposes, different periods within the last century are considered.

\section{The First Years of the XX Century}

The most outstanding contributions to Chemistry at the beginning of the $\mathrm{XX}$ century were related to the perception of atomic constitution of matter. In this context, Analytical Chemistry had already provided a relevant contribution in earlier periods, especially after the availability of the analytical balance and the systematic studies that led to the discovery (or postulation) of the elements. As a consequence of these studies, mass spectrometry underwent pronounced progress at the beginning of $\mathrm{XX}$ century, leading to the sedimentation of the atomic theory and the discovery of isotopes. ${ }^{3}$ Another important instrument in this context was the cathode-ray tube, still exploited in several modern instruments.

The discovery of radioactivity and a better understanding of the natural radioactive series resulted in further progress of Analytical Chemistry, especially with regard to separation procedures and determination of long- lived radionuclides. ${ }^{3,4}$ At this time, the first investigations with X-ray diffraction were carried out and chromatography was defined, as a consequence of plant pigment separation by the Russian scientist Tsvett, in Warsaw. ${ }^{5,6}$ Other topics relevant to the progress of Analytical Chemistry were the inception of atomic absorption spectrometry, ${ }^{7}$ investigations related to analytical applications of coordination chemistry and the maturation of classical analytical procedures with emphasis on biomedical, metallurgical and environmental applications.

\section{First Half of XX Century}

In this period, an exponential growth in the demand for chemical assays was noted, especially because quality control became a "must" and clinical chemistry was recognized worldwide as a relevant discipline. Within the Analytical Chemistry/Chemical Analysis dichotomy, landmark advances were reported, but to specify the most expressive contributions in the period is really a very hard task. The continuous development of polarography (after Heyrovsky, 1922) and spectrophotometry (after Beckmann, 1932) may, however, be considered as landmark contributions and should be highlighted. During the 30's and 40's important scientific and technological advances, such as the first nuclear activation analysis (Hevesy and Levi, 1936), the description of partition chromatography and the conception of gas-liquid chromatography (Martin and Synge, 1941) should be noted. This latter was fundamental for the appearance of the first gas chromatographs (Cremer, 1951; Martin and James, 1952) and for the amazing developments in both gas and liquid chromatography that started in the fifties.

It is interesting to observe that, up to the 40's, most of the scientific results were communicated as letters to scientific associations, presentations at scientific congresses, letters to collaborators and/or academic theses. Publication in scientific journals was less emphasized.

In Brazil, Analytical Chemistry was generally thought of as a basic discipline, although it was also considered a tool to assist research linked to the other disciplines. In this period, the first laboratories dedicated to the development and application of analytical procedures were implemented. In 1916, the Brazilian Academy of Sciences was founded ${ }^{8}$ and this was a driving force towards further scientific progress.

Scientific development in Brazil was strongly influenced by the immigration of a number of prominent scientists, ${ }^{9,10}$ who left their previous working places before the Second World War (1939-45). Regarding Analytical Chemistry, the coming of Fritz Feigl to Rio de Janeiro 
should be emphasized. He had already authored his famous textbook on spot tests ${ }^{11}$ and became one of the pioneers of modern Analytical Chemistry in Brazil. In this context, the work of Paschoal Senise (doctorate from Universidade de São Paulo, 1940) and the start of a worldwiderecognized group at that Institution should be highlighted.

\section{The Golden Age: Renaissance After War}

After the Second World War, effervescence in terms of scientific and technological advances was observed, mainly during the fifties. Nuclear activation analysis, column chromatography (GC and HPLC) and electroanalytical techniques started being widely utilized, the Ilkovic equation - related to polarographic techniques - was derived, and flow analysis was conceived (Skeggs, 1951). Initial research aiming at exploitation of reaction kinetics in Analytical Chemistry that culminated with the appearance of the first book on catalytic methods of analysis by Yatsimirskii, ${ }^{12}$ the overall acceptance of infrared spectrometry for practical applications, and the construction of the first atomic absorption spectrometer by Sir Alan Walsh in $\mathrm{CSIRO}^{13}$, should be also mentioned.

Regarding adherence, it should be noted that Analytical Chemistry in Brazil was in close harmony with the abovementioned achievements. In fact, and only to mention some, the nuclear research reactor (at IEA, today IPEN),${ }^{14}$ the initial applications of polarographic (and similar) ${ }^{15}$ as well as chromatographic ${ }^{16,17}$ procedures, the utilization of flow analysis mainly in clinical laboratories, ${ }^{18}$ the appointment of Fritz Feigl as a member of the first Editorial Board of Analytica Chimica Acta, analytical support to the investigations on Natural Products, and the initial steps of construction of an atomic absorption spectrometer (Figure 3) should be highlighted. In the 1950-70 period, the contributions of the Brazilian scientists to Analytical Chemistry could be also noted in terms of methodological and applicative achievements, as demonstrated by the several analytical methods proposed, some of them accepted as reference methods. ${ }^{19,20}$ The pioneering book by Ohlweiler ${ }^{21}$ played a relevant role in this context.

A critical analysis of the development of Analytical Chemistry in Brazil in the period, especially during the 50 's, reveals that most of the work was done by a small number of scientists located mainly in Rio de Janeiro and Sao Paulo. As noteworthy exceptions, the research groups headed by Antonio Celso Spinola Costa in Salvador, Otto Alcides Ohlweiler in Porto Alegre and other pioneers in different regions should be recognized here.

In order to expand science and to strength research in a national context, $\mathrm{CNPq}$ was founded in $1951 .{ }^{22}$ This led to

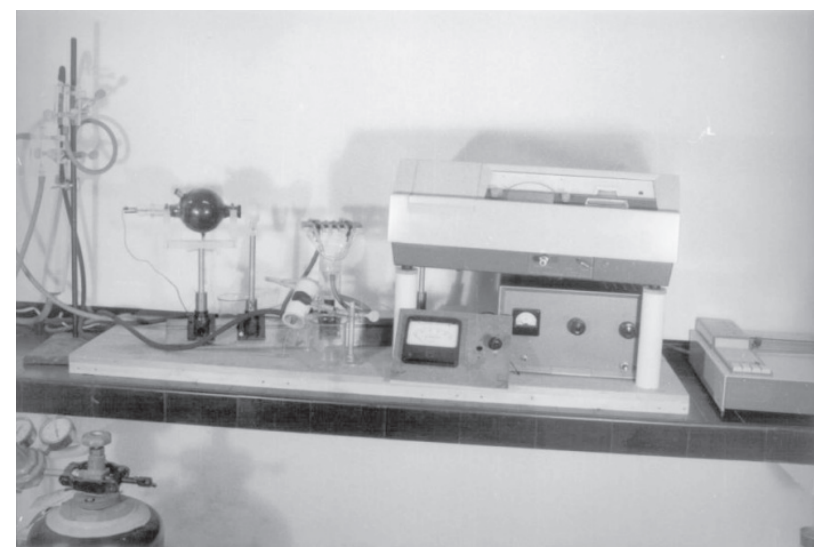

Figure 3. The first atomic absorption spectrometer constructed in Latin America. From left, gas reservoir (bottom) with tubing, magnesium hollow cathode lamp, sample introduction port (platform type), flame, Beckman DBG spectrophotometer acting as a FAAS detector placed on a power supply and strip-chart recorder. Instrument designed during the sixties and presented at ESALQ/USP in 1967 (Bergamin's appointment as "Livre Docente"). The photo is original, provided as a courtesy by F.J. Krug. Other specific photos available upon request to him.

an amazing increase of the development of Analytical Chemistry in Brazil that manifests itself up to the present.

During the 60's and 70's, scientific progress has continued. Man was looking at space and the well known "space race" was at its peak, pushing the development of science. On the subject of Analytical Chemistry, several outstanding contributions, such as, e.g., ion chromatography, flow injection analysis and electrothermal atomization (Massmann furnace) in atomic absorption spectrometry, were proposed. In 1964, stable inductively-coupled argon plasmas were obtained ${ }^{23,24}$ and this proved to be essential in relation to atomic emission and mass spectrometry. A noteworthy growth in the number of data produced was noted, requiring more and more complex data treatment; this was the driving force towards the development of chemometrics as applied to Analytical Chemistry. In the 70's, the International Society for Chemometrics was founded with three Brazilian members.

Brazilian adherence to these international achievements was, however, relatively low, although credit should be given to some pioneering research work, e.g., singlephase liquid-liquid extraction and flow-injection analysis, carried out by the groups headed by Martins ${ }^{25}$ and Bergamin Filho, ${ }^{26}$ respectively. In this context, the pioneering application of flow-injection analysis on a routine basis ${ }^{27}$ should be stressed.

In the period, several important institutions were established in Brazil as a consequence of a governmental decision: all Brazilian states should have at least one public university. This led to a pronounced dissemination of 
Analytical Chemistry, which motivated the sedimentation of concepts, and further achievements that are still in course.

In relation to teaching, relevant contributions from different states, including the appearance of influential books by Brazilian authors ${ }^{28}$ or translations to Portuguese should be reported. This tendency has continued up to the present and the book on quantitative analysis by Baccan et $a l .{ }^{29}$ is nowadays essential in undergraduate courses. In short, this period in Brazil was characterized by less scientific innovation and more dissemination in relation to other periods mentioned here.

By the end of the 70's, Analytical Chemistry was already a separate and reasonably well-developed discipline in Brazil.

\section{The 80's and 90's: Microcomputers in the Laboratory}

Landmark advances mainly related to bio-analytical chemistry, sensors, miniaturization, instrumentation etc., characterized the 80 's. The presence of the microcomputer in the laboratory and the design of computer-controlled devices were more and more frequent.

In Brazil, this became a limiting factor against development because the government decided to prevent the importation of equipment and materials if there was a "similar" product made in Brazil. This was done with the intent to protect the nascent Brazilian microcomputer industry; therefore the acquisition of these machines, in particular, was strongly limited. This constituted an "Achilles Heel" for the progress of Analytical Chemistry in Brazil. However, in spite of this restriction, the Brazilian scientific community reacted in order to circumvent it, and a favorable situation in terms of number of publications, size of graduate programs, industrial applications etc., was attained. ${ }^{30}$ Several industries and/or company representatives, aiming at the introduction of novel instruments and methods into the Brazilian market were established, and there was additional support for further development. It is interesting to note that different techniques, such as nuclear magnetic resonance, mass spectrometry, X-ray fluorescence, thermal analysis, novel separation techniques etc., as well as hyphenated techniques were already available in several laboratories.

At the beginning of the eighties, the first National Meeting on Analytical Chemistry (ENQA) was held at the Pontifícia Universidade Católica, Rio de Janeiro. ${ }^{31}$ The meeting was attended by 108 participants; in the last edition of ENQA (Universidade Estadual de Campinas, 2001) this number surpassed 1000 , reflecting a 10 -fold increase.
The reader more interested in quantitative aspects of the development of Analytical Chemistry in Brazil may refer to the articles by Senise (1985) $)^{31}$ and, more recently, by Fatibello-Filho et al. ${ }^{33}$ and by Oliveira Neto et al. ${ }^{34}$

\section{Recent Years: Effervescence}

Paradoxically, and repeating the beginning of the century, an effervescence was noted again at the end of the millennium. Modern topics such as analytical biochemistry, genetic techniques, environmental chemistry, medical diagnosis, genomics and proteomics, high-throughput screening analysis, sensors, chemometrics (emphasis on chemical imaging), nano-analytics, lab-on-a-chip, $\mu$-TAS, industrial process analyses, metrology, art and history, waste management, etc. are presently under active development, ${ }^{35}$ as well as emphasis to terminology and improvements in teaching.

In Brazil, landmark achievements have been noted but not well balanced among all the above-mentioned fields. The impact of the Brazilian contribution can be evaluated by considering that $1.01 \%$ of all papers published in 2001 were produced in Brazil. ${ }^{30}$ The tendency holds in the context of Chemistry, where the number of publications grew from $836(1990 / 91)$ to 4658 (1998/2000) and a pronounced increase in the number of citations has been observed. Analytical Chemistry follows this tendency in view of its interdisciplinary character. A noteworthy aspect of scientific production in Brazil is that most of the academic research is done within the graduate programs. For quantitative data, the reader should refer to, e.g., the CAPES (Coordenação de Aperfeiçoamento de Pessoal de Nível Superior) homepage (www.capes.gov.br).

\section{Trends}

Advances in Analytical Chemistry, including conceptual, methodological and applicative attainments (and eventually patents), should always be aimed at the solution of real problems. As research, teaching and application are always linked, one can conclude that "the day when we learn (or teach) something is a happy day". ${ }^{36}$ In order to present tendencies, it is interesting to stress that the number of out-of-laboratory samples assayed is increasing, especially in recent years. In a worldwide context, before the 80 's less than $5 \%$ of the analyses were accomplished outside the traditional laboratory; this number approached $50 \%$ at the turn of the millennium. ${ }^{37}$ The size of today's instruments has generally been continuously reduced, so that it is nowadays difficult to find instruments as large as those produced in the 70's or 
80's. Progressive attention has been given to instrumental miniaturization and reduced consumption of samples and reagents, thus minimizing generation of waste. Use of toxic and/or carcinogenic reagents is progressively discouraged. These features are in agreement with the modern tendency towards a "Green Chemistry". 38

Another interesting aspect is the publication policy. In view of the increasing demand for publishing, prestigious scientific journals have strengthen their criteria for accepting manuscripts for publication. ${ }^{39,40}$ This will certainly result in an improvement of quality. Moreover, several periodicals are being extinguished and/or merged, an important example being the new Analytical and Bioanalytical Chemistry that resulted from the coalescence of Fresenius' Journal of Analytical Chemistry (Germany), Analusis (France) and Quimica Analitica (Spain).

Consequently, a modification in the paradigm is now being observed. Aspects more related to bio-analytical, in situ and in vivo assays, remote sensing and methods with low quantities of produced residues, tend to be emphasized. The need for quality control is also increasing; therefore priority is being given to other aspects such as chemometrics, accreditation, traceability, accuracy etc. Design of more versatile analytical instrumentation is another tendency. The duality of chemical equilibrium/ kinetics is again under focus. Although the proposal of novel procedures is presently less emphasized, the tendency to accommodate several procedures in a single instrument or, in other words, to have a kind of normalization process, is foreseen. This favors the development of polyvalent analytical systems and is in agreement with the nostalgic expression "no more new methods, please". The above-mentioned shift in paradigm is summarized in Figure 4. Analysis of this Figure in relation to identity, adherence, domain and divulgation permits a final reflection of the present status of Analytical Chemistry in Brazil.

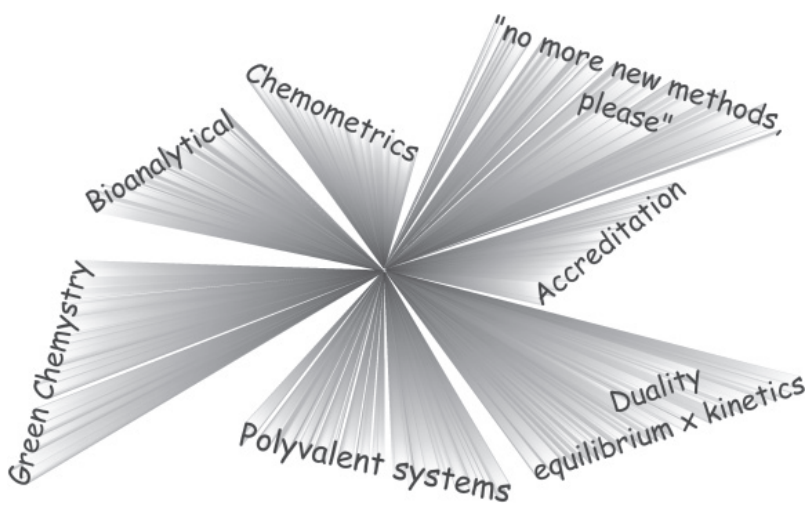

Figure 4. Main aspects in modern Analytical Chemistry.

\section{Ackowledgements}

The authors thank the Editors of this Special Issue for this opportunity and apologize for any contributions that may have been forgotten. Critical comments by C.H. Collins, F.J. Krug and B.F. Reis are acknowledged. The Brazilian funding agencies are thanked for their contribution to the development of Analytical Chemistry.

\section{References}

01. Senise, P.E.A.; Quim. Nova 1982, 5, 137.

02. Valcarcel, M.; Fresenius J. Anal. Chem. 1992, 343, 814.

03. Kaplan, I.; Física Nuclear, $3^{\text {rd }}$ ed., Aguilar: Madrid, 1970.

04. Friedlaender, G; Kennedy, J.W.; Macias, E.S.; Miller, J.M.; Nuclear and Radiochemistry, $3^{\text {rd }}$ ed., Wiley-Interscience: New York, 1981.

05. Nieuwkerk, H.J.; Hewlett-Packard J. 1990, 41, 7.

06. Collins C.H. ; Braga, G.L.; Bonato, P.S.; Introdução a Metodos Cromatográficos, $7^{\text {th }}$ ed., Editora UNICAMP: Campinas, 1997.

07. Pinta, M.; Atomic Absorption Spectrometry, Adam Hilger: London, 1975.

08. Academia Brasileira de Ciências; Anuário da Academia Brasileira de Ciências, Academia Brasileira de Ciências: Rio de Janeiro, 2000.

09. Schwartzman S.; Ciência Hoje 1990, 11, 12.

10. Feigl, F. In Os Cientistas; Civita, V., ed.; Editora Abril: São Paulo, 1973, vol. 44, p. 717.

11. Feigl, F. In Mikrochemisches Praktikum: eine Einleitung zur Ausfuerung der wichtigsten mikrochemischen Handgriffe, Reaktionen und Bestimmungen mit Ausnahme der Quantitativen organischen Mikroanalyse; Emich, F. ed., J.F. Bergmen: Munich, 1931; Feigl, F.; Qualitative Analysis by Spot Tests: Inorganic and Organic Applications, Elsevier: New York, 1937.

12. Yatsimirskii, K.B. In International Series of Monographs in Analytical Chemistry; Belcher, R.; Gordon, L., eds.; Pergamon Press: London, 1966, vol. 25.

13. Walsh, A.; Spectrochim. Acta 1955, 7, 108.

14. http://www.ipen.br/ipen_p/historico/historico-galeriafotos.html; acessed in October 2002; Leão, R.M.; Trinta Anos em CENA, Edusp: Sao Paulo, 1997.

15. Neves, E.A.; Senise, P.; J. Am. Chem. Soc. 1961, 83, 333.

16. Ciola, R.; Cromatografia de Gas, Departamento de Engenharia Química - USP: São Paulo, 1961; Ciola, R.; Introdução à Cromatografia em Fase Gasosa, Edgard Blücher: São Paulo, 1973.

17. Abrao, A.; Operações de Troca Ionica, Instituto de Energia Atômica: São Paulo, 1972.

18. Snyder, L.R.; Anal. Chim. Acta 1980, 114, 3.

19. Fries, J.; Getrost, H.; Organische Reagenzien fuer die Spurenanalyse, Merck: Darmstadt, 1975, p. 98. 
20. Catani, R.A.; Alcarde, J.C.; Manual de Controle de Qualidade de Fertilizantes, Associação Nacional para Difusão de Adubos (ANDA): São Paulo, 1973.

21. Ohlweiler, O.A.; Teoria e Métodos da Análise Quantitativa, Ministério da Educação e Cultura, Instituto Nacional do Livro: Rio de Janeiro, 1957.

22. Vargas, J.I. In Science in Brazil; Carvalho, A.C.C.; Campos, D.A.; Bevilacqua, L. eds, Academia Brasileira de Ciências: Rio de Janeiro, 2002, p. 9.

23. Greenfield, S.; Berry, C.T.; Jones, I.L.; Analyst 1964, 89, 713.

24. Wendt, R.H.; Fassel, V.A.; Anal. Chem. 1965, 37, 920.

25. Martins, J.W.; PhD Thesis, Universidade Estadual de Campinas: Campinas, 1974

26. Stewart, J.W.B.; Ruzicka, J.; Bergamin Filho, H; Zagatto, E.A.G.; Anal. Chim. Acta 1976, 81, 371.

27. Ruzicka, J.: Hansen, E.H.; Trends Anal. Chem. 1998, 17, 69.

28. Ohlweiler, O.A.; Química Inorgânica, Edgard Blücher/EDUSP. São Paulo, 1971.

29. Baccan, N.; Andrade, J.C.; Godinho, O.E.S.; Barone, J.S. Química Analítica Quantitativa Elementar, $3^{\text {rd }}$ ed., Edgard Blücher: São Paulo, 2001.

30. Carvalho, A.C.C.; Campos, D.A.; Bevilacqua, L. eds. ; Science in Brazil, Academia Brasileira de Ciências: Rio de Janeiro, 2002.
31. Departamento de Química da Pontifícia Universidade Católica do Rio de Janeiro; $1^{\circ}$ Encontro Nacional de Química Analítica, Livro de Resumos, PUC-Rio: Rio de Janeiro, 1982.

32. Senise, P.; Anal. Lett., 1985., 18, 1933.

33. Fatibello-Filho, O.; Neves, E.F.A.; Rocha, F.R.P.; Nóbrega, J.A.; Quim. Nova, 2002, 25, 62.

34. Oliveira Neto, G.; Cadore, S.; Kubota, L.T.; Anal. Lett. 2001, 34, 471.

35. Division of Analytical Chemistry of the Federation of European Chemical Societies; Euroanalysis 12, Book of Abstracts, DAC/FECS: Dortmund, 2002.

36. Bergamin Filho, H.; Personal Communication, 1994; addition in parenthesis by O.R. Gottlieb, 1999.

37. Korte, E.H.; Personal Communication, X Euroanalysis: Lisbon, 2000

38. De la Guardia, M.; Ruzicka, J.; Analyst 1995, 120, 17N.

39. Christian, G.D.; Kauffman, J.M.; Talanta 1998, 47, 1.

40. Thompson, M.; Greenway, G.; Analyst 2002, 127, 3.

Received: October 19, 2002 Published on the web: April 11, 2003

FAPESP helped in meeting the publication costs of this article. 